\section{Et genfundet middelalderligt lædersnitbogbind}

\author{
Afcand. phil. Karsten Christensen
}

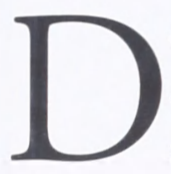
et Kongelige Bibliotek har i sine samlinger et ikke ringe antal senmiddelalderlige bogbind.

Mange af disse sidder omkring håndskrifter og gamle tryk, som kom til biblioteket 1735-49 som krigsbytte fra Gottorp Slot i Slesvig. Hertil var de tidligere af hertugerne blevet indsamlet fra især klosterbibliotekerne i Bordesholm og Cismar.

Nedenstående er mest af alt en påmindelse til os selv og kommende slægter om, at der i KBs samlinger findes et på disse breddegrader ganske bemærkelsesværdigt senmiddelalderligt bogbind omkring et vistnok ikke specielt bemærkelsesværdigt, men dog ikke nærmere undersøgt latinsk papirhåndskrift i folioformat, der indeholder en middelalderlig kommentar til et par af den græske filosof Aristoteles dengang mest læste skrifter ${ }^{1}$. Efter skriften og oksehovedvandmærkerne at dømme er håndskriftet fra 1400-tallet, men uden angivelse af, hvem der har skrevet det eller hvor det er skrevet. Gamle bibliotekssignaturer viser dog klart, at det har været en del af biblioteket i augustinerklostret i Cismar i Holsten og at det via biblioteket på Gottorp er kommet til Det Kgl. Bibliotek, hvor det har signaturen Gammel Kongelig Samling (GKS) nr. 215.

Det ganske særlige ved bindet om håndskriftet er, at det er et såkaldt lædersnitbogbind. Det vil grundlæggende sige et læderovertrukket bind, hvorpå der med en kniv er skåret en dekoration, der med forskellige teknikker er tydeliggjort. Teknikken er meget gammel, men når det drejer sig om bogbindsdekoration i Europa, er det en metode, der stort set begrænser sig til 1400-tallet og geografisk først og fremmest er knyttet til det mellemste og sydlige Tyskland og Østrig. Bindene må i sammenligning med de almindelige gotiske stempeldekorerede eller udekorerede bind anses for luxusbind, som der så vidt vides kun er bevaret små 400 af i alt, og som i den europæiske, særligt den tysksprogede, bogbindslitteratur siden omkring år 1900 har givet anledning til megen opmærksomhed. Nye fund bliver øjeblikkeligt offentliggjort i de bedste tidsskrifter.

\section{Tidligere omtaler af lædersnitbindet} Det Kongelige Biblioteks lædersnitbind omkring GKS 215 er imidlertid ikke et nyfund, men det er tilsyneladende så at sige gået i glemmebogen, hvad det bestemt ikke fortjener. Da biblioteket i forbindelse med indflytningen i Holm-nybygningen i 1908 åbnede en stor permanent udstilling af, som det hedder ${ }^{2}$ : ,interessante Haandskrifter, Tryk, Bogbind, Autografer og Billeder osv. i Lighed med dem, der findes ved Udlandets store Biblioteker" blev GKS 215 inkluderet specielt blandt bogbindene, selvfølgelig fordi det var noget særligt. I kataloget fra $1908^{3}$ har bindet udstillingsnr. 585. Men teksten leder desværre ikke tanken hen på et lædersnitbind. Det oplyses kun, at bindet er udført i 15. årh. „, Cismar-Klostret ved Lübeck. Den gamle Signatur fra Klosterbiblioteket ses paa Siden“.

Denne unægtelig summariske omtale skyldtes vist nok ikke manglende viden, men var blot en konsekvens af katalogens generelt kursoriske tekst. At man i København på det tidspunkt vidste, at 


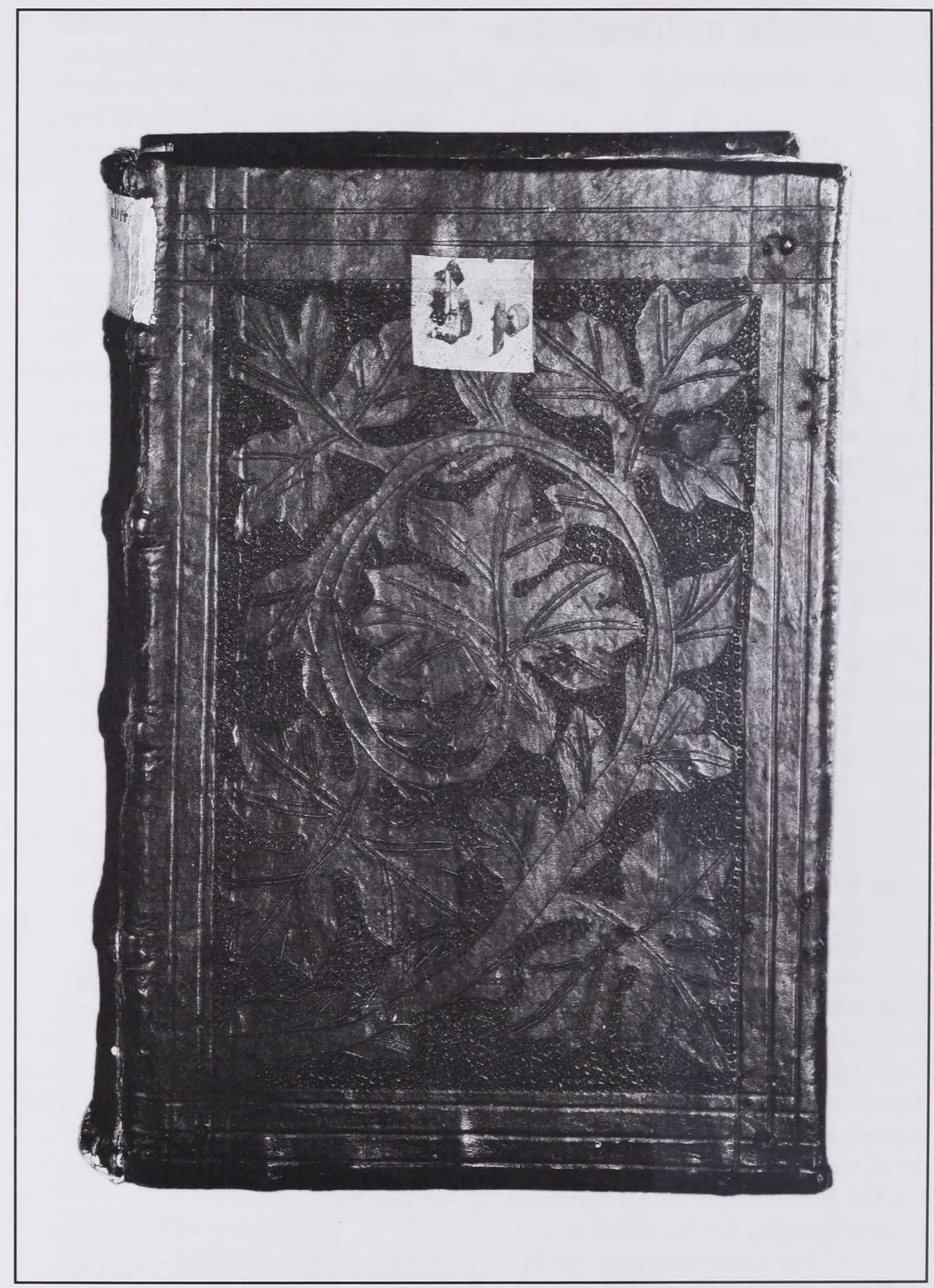

Bindet om GKS (Gammel Kongelig Samling) nr. 215. De starkt indskårne og fligede blade dakker inden for en yderramme forsiden i én enkelt slynget, bladbesat gren. (Det Kgl. Bibliotek). 


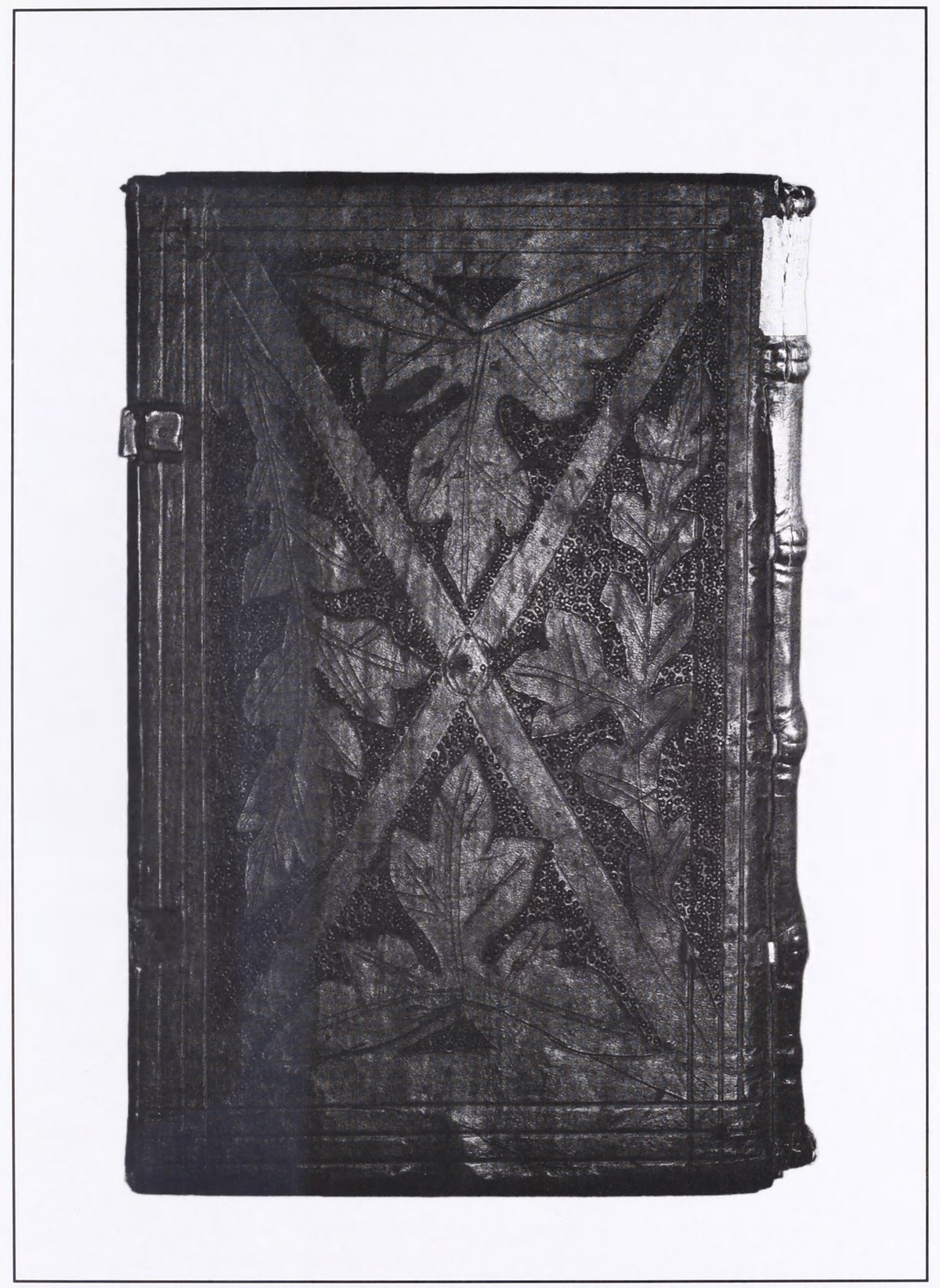

Bagsiden, der er opdelt af diagonale rammer, dakkes affire enkeltstående blade. (Det Kongelige Bibliotek). 
lædersnitbind var noget særligt, fremgår f.eks. af katalogen over den kort tid før afholdte store bogbindsudstilling $\mathrm{i}$ Kunstindustrimuseet i begyndelsen af $1906^{4}$, hvor Emil Hannover i det indledende essay om bogbindene fra senmiddelalderen skriver:

„Læderbindet var i færd med at blive almindeligt. Det forfærdigedes i Middelalderen (og nogle Steder langt ind i Renaissancetiden) paa Underlag af $T_{r} \boldsymbol{\alpha}$; Skindet, der anvendtes, var Kalveskind eller Svineskind; Dekorationen frembragtes ved Ladersnit eller Blindtryk. Lædersnittets Teknik bestod $\mathrm{i}$ at indridse Tegningen i det vaade Læder og uddybe Ridsene med et stumpt instrument, hvorefter Mønstret fremhævedes ved at trænge Grunden tilbage med Punsler eller om fornødent- ved Drivning bagfra. Det var en Frihåndsteknik, hvorved der kunne opnaas stor Friskhed i Arbejdet, men som ogsaa krævede kunstnerisk Evne, lang Øvelse og stor Taalmodighed. Uendeligt hyppigere brugtes derfor i Middelalderen Blindtrykket ......"

Forunderligt nok vistes der ikke på udstillingen i Kunstindustrimuseet noget lædersnitbind, men typen var altså velkendt $\mathrm{og}$ kunne som nævnt kort tid senere ses af offentligheden i Det Kongelige Biblioteks permanente udstilling, der først blev nedtaget i 1939.

I bibliotekets trykte katalog (1923-26) over de middelalderlige latinske håndskrifter har Ellen Jørgensen naturligvis også kort nævnt, at indbindingen af GKS 215 var dekoreret ved indskæringer i læderet ${ }^{5}$.
Det virker derfor overraskende, at bindet ikke blev medtaget i Anker Kysters (og Johannes Bonnesens) storværk: Bookbindings in the Public Collections of Denmark Vol. I: The Royal Library, Copenhagen. 1938. Og mig bekendt har bindet heller ikke senere af biblioteket offentligt været udstillet eller nævnt blandt dets skatte.

Til gengæld har tysk bogbindsforskning kendt bindet. Det er således omtalt udførligt af den tyske bogforsker Max Joseph Husung i $1940^{6}$, angiveligt på grundlag af oplysninger fra Victor Madsen på Det kgl. Bibl. og på baggrund heraf er bindet optaget og beskrevet af F.-A. Schmidt-Künsemüller i standardværket Corpus der gotische Lederschnitteinbände aus dem deutschen Sprachgebiet. Stuttgart 1980, der registrerer og karakteriserer alle dengang kendte bind. I dette værk bringes nyoptagne, men desværre ikke særligt gode sort/hvide fotos af både for- og bagside af bindet om GKS 215.

\section{Dekorationer}

Lædersnitbind adskiller sig som nævnt fra tidens øvrige bogbind ved dekorationsmetoden. Valget af motiver er rigt varieret. Man ser figurlige fremstillinger af løver, heste, drager, hunde og slanger. Alle mulige blomster og planteformer, geometriske og menneskelige figurer, indskrifter, bogstaver osv. Hele den sengotiske billedverden er repræsenteret. Bindet om GKS 215 er ganske karakteristisk for en større gruppe af de nu kendte 1400-tals lædersnitbind, ved at være holdt i en enkel, kunstnerisk ganske sikker form alene med gengivelse af, hvad Schmidt-Künsemüller identificerer som lindeblade på såvel forsiden som bagsiden af bindet. De stærkt indskårne og fligede blade (hvis botaniske forbillede ikke her skal 


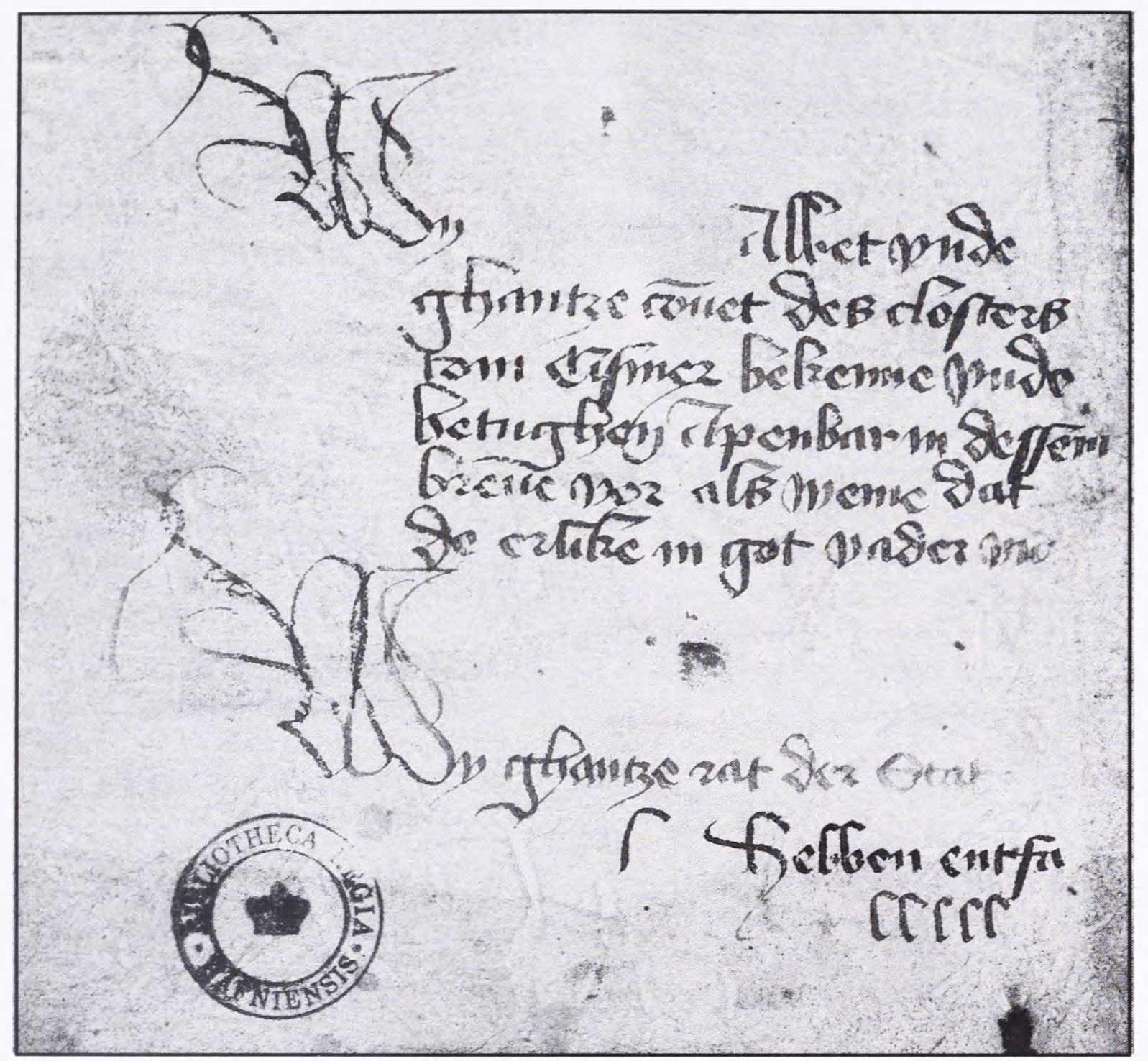

En detalje fra indersiden af det middelalderlige ladersnitbogbind. (Det Kongelige. Bibliotek).

drøftes nærmere) dækker inden for en yderramme forsiden i én enkelt slynget, bladbesat gren, mens bagsiden, der er opdelt af diagonale rammer, dækkes af fire enkeltstående blade. Baggrunden er omhyggeligt indpunslet med små cirkelformede, muligvis sortfarvede, markeringer, der lader bladtegningerne træde tydeligere frem fra bindfladen. Bagsiden er ikke udført meget ringere end forsiden, hvad ofte angives at være tilfældet.

\section{Hvor stammer bindet fra?}

Selvom der fra bogbindsforskernes side ${ }^{7}$ er gjort mange anstrengelser for at gruppere kendte bogbind i værksteder, synes det ikke umiddelbart indlysende at placere dette bind $\mathrm{i}$ en af de hidtil nærmere beskrevne grupper, således at man naturligt kunne forklare forekomsten af et lædersnitbind i et holstensk kloster, som et spørgsmål om import af et enkelt indbundet håndskrift sydfra. Det kunne måske forekomme at være en meget nærliggende forklaring på forekomsten af bindtypen så nordligt, men der er ikke desto mindre forhold ved håndskriftet, der vækker en vis tvivl. Til forpermens inderside er knyttet et stykke pergament, der går i hele bindets højde, men kun er halvt så bredt 
som bindet. Det er på indersiden påført nogle nedertyske penne- eller snarere skriveprøver af en senmiddelalderlig skriver. Bl.a. ses teksten til begyndelsen af et brev udstedt af Cismarklostret: „Wy abbet vnde ghantze conuent des Closters fam (!) Cismer bekenne ...." og til et tilsvarende udstedt af borgmester og råd i Lübeck: „Wy borghermeister vnde ratma $n$ der Stad Lube bekenne vnde bethugen openbar in desse .. breue dat...".

Hvis dette pergamentsstykke inklusive de påførte skriveprøver er et kasseret biprodukt fra en skriverstue, og hvis det herefter af bogbinderen er blevet knyttet til håndskriftet i forbindelse med indbindingen, så er der grund til at antage, at indbindingen og vel også dekoreringen af bindet er foregået i Cismar, og så er der altså ikke tale om import af håndskrift og bind, men givetvis tale om en såkaldt vandrerbogbinder, måske verdslig, måske en (augustiner)munk sydfra, der har vist sin kunst her. Sådanne bogbindere er velkendte i andre sammenhænge. Denne mulighed må først og fremmest overvejes i lyset af, at det må forekomme noget overraskende, hvis en munk i Cismar skulle have øvet sig i at formulere breve ved direkte at skrive i klosterbibliotekets Aristoteleskommentar. Fremtiden vil utvivlsomt kunne svare sikrere på ophavsspørgsmålet, så hermed er nu blot bemærket, at Det Kongelige Bibliotek er i besiddelse af et fint eksemplar af disse ganske specielle og sjældne bogbind. ${ }^{8}$

Noter

1. Jeg er docent, dr. phil. Sten Ebbesen, Københavns Universitet, taknemmelig for oplysninger vedr. indholdet af GKS 215.
2. Aarsberetning for det kongelige Bibliotek for 1906-1909. København 1909. s. 40.

3. Katalog over Det kongelige Biblioteks permanente Udstilling. København 1908. S. 67.

4. Katalog over Udstillingen af kunstfardige gamle Bogbind indtil 1850. Med en Indledning om Bogbinderkunstens Historie af Emil Hannover. København Januar 1906.

\section{Catalogus codicum latinorum medii avi} Bibliotheca regia Hafniensis. Digessit Ellen Jørgensen. Hafniæ MCMXXIII-VI. P. 443: „est in tabulis corio tectis frontibus incisis decorato."

6. Husung, M. J.: Programmatisches und Kritisches zu einem Atlas bzw. Corpus derLederschnitteinbände des Mittelalters. Archiv für Buchbinderei. Zeitschrift für Einbandkunst Jahrg. XL, heft 7. Halle 1940. S. 53-55. Jeg takker afdelingsbibliotekar Susanne Budde for oplysning om, at (dele af) dette tidsskrift i Danmark findes på Kunstindustrimuseet.

7. Af nyere samlede fremstillinger kan f.eks. henvises til Otto Mazal: Einbandkunde. Die Geschichte des Bucheinbandes. Elemente des Buch-und Bibliothekswesens. Herausgegeben von Günter Gattermann und Richard Landwehrmeyer. Bd. 16. Wiesbaden 1997. S. 76-95.

8. Der henvises i øvrigt i det hele til Harald Ilsøes tankevækkende betragtninger om individuel og kollektiv hukommelse i: Inden for murene. Bibliotekets ,skatte' set i et tilbageblik. Magasin fra Det kongelige Bibliotek. 8. årg. nr. 4. marts 1994. s 8-25 Dette er tænkt som et lille bidrag til løsning af en stor og forhåbentlig aldrig afsluttet opgave. 